\title{
Corn root morphoanatomy at different development stages and yield under water stress
}

\author{
Thiago Corrêa de Souza(1), Paulo César Magalhães(2), Evaristo Mauro de Castro(3), \\ Vinícius Politi Duarte ${ }^{(1)}$ and Alyne Oliveira Lavinsky(2)
}

\begin{abstract}
(1)Universidade Federal de Alfenas, Instituto de Ciências da Natureza, Rua Gabriel Monteiro da Silva, no 700, Centro, CEP 37130-000 Alfenas, MG, Brazil. E-mail: thiago.souza@unifal-mg.edu.br, viniciuspoliti@hotmail.com ${ }^{(2)}$ Embrapa Milho e Sorgo, Rodovia MG-424, Km 45, CEP 35701-970 Sete Lagoas, MG, Brazil. E-mail: paulo.magalhaes@embrapa.br, alynelavinsky@gmail.com (3)Universidade Federal de Lavras, Departamento de Biologia, Setor de Fisiologia Vegetal, Caixa Postal 3037, CEP $37200-000$ Lavras, MG, Brazil. E-mail: emcastro@ufla.br
\end{abstract}

\begin{abstract}
The objective of this work was to characterize the morphoanatomy of roots and the yield traits of two corn hybrids contrasting for drought tolerance (DKB 390, tolerant; and BRS 1030, sensitive), at different stages of development. Water deficit was imposed for ten days, in a greenhouse, at three growth stages: V5, VT, and R3. These treatments were combined to generate cumulative stress during the plant cycle, as: V5VT, V5R3, VTR3, and V5VTR3. The following were analyzed: root anatomy; proportion of aerenchyma in the cortex; metaxylem number and diameter; phloem thickness; as well as morphological characteristics, such as root length, volume, and surface area, specific root length, length of fine roots, grain yield, and ear length and diameter. Development stage affected the responses to stress: DKB 390 showed the best performance for root morphoanatomy and yield traits, under drought stress, at the reproductive stages, mainly R3, and in the treatments with cumulative stress, especially V5VTR3; whereas BRS 1030 presented higher means for the studied parameters, mainly at the V5 and VT stages, but did not show a higher grain yield under water stress. The greater tolerance of the DKB 390 hybrid to water deficit is probably linked with a memory of pre-exposure to water stress at different growth stages.
\end{abstract}

Index terms: Zea mays, aerenchyma, drought, endoderm, specific root length, WinRhizo.

\section{Morfoanatomia radicular em diferentes estádios de desenvolvimento e produtividade do milho sob estresse hídrico}

Resumo - O objetivo deste trabalho foi caracterizar a morfoanatomia radicular e os atributos de rendimento de dois híbridos de milho contrastantes quanto à seca (DKB 390, tolerante; e BRS 1030, sensível), em diferentes estádios de desenvolvimento. A deficiência hídrica foi imposta por dez dias, em casa de vegetação, em três estádios de desenvolvimento: V5, VT e R3. Esses tratamentos foram combinados para gerar estresses acumulativos durante o ciclo da planta, como: V5VT, V5R3, VTR3 e V5VTR3. Foram analisados: anatomia radicular; proporção de aerênquima no cortex; número e diâmetro de metaxilema; espessura do floema; bem como características morfológicas, como comprimento, volume e área de superfície radicular, comprimento específico das raízes, comprimento de raízes finas, rendimento de grãos, e comprimento e diâmetro da espiga. O estádio de desenvolvimento influenciou as respostas ao estresse: DKB 390 apresentou o melhor desempenho quanto à morfoanatomia radicular e aos atributos de rendimento, quando submetido a estresse hídrico, nos estádios reprodutivos, sobretudo em R3, e nos tratamentos acumulativos de estresse, principalmente no V5VTR3; enquanto BRS 1030 apresentou as maiores médias para os parâmetros estudados, principalmente nos estádios V5 e VT, mas não apresentou maior rendimento de grãos sob estresse hídrico. A maior tolerância do híbrido DKB 390 ao estresse hídrico provavelmente relaciona-se à memória de exposição prévia ao estresse hídrico em diferentes estádios de desenvolvimento.

Termos para indexação: Zea mays, aerênquima, seca, endoderme, comprimento específico radicular, WinRhizo.

\section{Introduction}

Corn (Zea mays L.) is a highly demanding plant in terms of water (Gong et al., 2015). Therefore, there may be reduced grain yield depending on the genetic material used and on the intensity and duration of drought stress during the plant cycle (Araus et al., 2012). 
Drought occurrence is more critical during some stages of the phenological cycle. At germination, for example, it reduces the number of plants per area (Magalhães \& Durães, 2008), whereas, in the vegetative stage, it reduces leaf area and, consequently, the photosynthetic rate and the accumulation of carbohydrates (Yan et al., 2016). At very early stages, such as V5, drought may reduce yield potential, since, at this time, floral differentiation occurs (Magalhães \& Durães, 2008). At the flowering period (VT), in which grain yield potential is determined, drought reduces the number of grains, leading to pollen desiccation, and, therefore, to an increase in the anthesis-silking interval and in early leaf senescence (Araus et al., 2012). Finally, during the grain filling period (R3), water deficit reduces the supply of assimilates at the source, leading to losses in grain weight (Khodarahmpour \& Hamidi, 2011).

Although it is well known that drought may occur at different stages of development and may also be accumulative, this information has been ignored until now in most researches. Therefore, major advances in understanding how corn plants respond to damages caused by drought have been based on evaluations performed on a single phenological stage (Khodarahmpour \& Hamidi, 2011; Ge et al., 2012; Lavinsky et al., 2015), and little is known about corn responses to the cumulative effect of drought throughout its cycle, i.e., in more than one development stage.

Morphoanatomical changes in the canopy and root system are involved in mechanisms for efficient water absorption and conservation, and the identification of such mechanisms is crucial for the selection of genotypes tolerant to drought ( $\mathrm{Zhu}$ et al., 2010; Ge et al., 2012). In corn, it has been shown that greater root length (Ali et al., 2016) and fewer lateral roots (Zhan et al., 2015) lead to an increase in drought tolerance. The size of the root cortex and the amount of aerenchyma are characteristics that are heritable and desirable in corn breeding for drought tolerance (Burton et al., 2015). In fact, Souza et al. (2013) observed that corn hybrids tolerant to drought have a greater proportion of aerenchyma in the root cortex. It should be noted that recent studies have focused on the characterization of morphoanatomical roots in genetic material of corn under drought conditions (Lavinsky et al., 2015). However, there is still a lack of details on these features, since the collection of material for analysis is hampered by the underground location of this organ of water capture (Kumar et al., 2012). No known work to date, therefore, has evaluated morphoanatomical features together with drought stress at different growth stages and cumulatively in corn hybrids contrasting for drought stress.

It has been suggested that the greater tolerance of some corn materials to drought stress is linked with the memory of pre-exposure to water deficit. It is possible that this memory of accumulated drought events induces morphological and anatomical adjustments at root level in order to explore water in deeper soil layers, which would allow significant improvements in grain yield attributes under drought conditions.

The objective of this work was to characterize the morphoanatomy of roots and yield traits of two corn hybrids contrasting for drought tolerance (DKB 390, tolerant; and BRS 1030, sensitive), at different stages of development.

\section{Materials and Methods}

Two hybrids contrasting for drought tolerance were used: DKB 390, which is tolerant; and BRS 1030, which is sensitive (Souza et al., 2013, 2014). The study was carried out in a greenhouse, at Embrapa Milho e Sorgo, in the municipality of Sete Lagoas, in the state of Minas Gerais, Brazil $\left(19^{\circ} 28^{\prime} \mathrm{S}, 44^{\circ} 15^{\prime} \mathrm{W}\right.$, at a $732-\mathrm{m}$ altitude). The average maximum and minimum temperatures recorded during the evaluation period were 30 and $22^{\circ} \mathrm{C}$, respectively, and the relative humidity ranged from 55 to $77 \%$. Two plants were used per 20 -L pot containing the soil type Latossolo Vermelho distrófico (Oxisol). Fertilization was done at planting, according to the recommendation of soil chemical analysis, with an $\mathrm{N}-\mathrm{P}_{2} \mathrm{O}_{5}-\mathrm{K}_{2} \mathrm{O}(5-20-20)$ formulation $+\mathrm{Zn}$, with doses of $1.15 \mathrm{~g} \mathrm{~kg}^{-1}$ soil. The plants were regularly irrigated in order to maintain the optimum soil moisture until stress imposition.

The water content in the soil was monitored daily, in the morning and in the afternoon, at 9:00 a.m. and 3:00 p.m., respectively, using a watermark moisture sensor (tensiometer), model 200SS-5 (Irrometer Company Inc., Riverside, CA, USA), installed in the center of the pots at a $20-\mathrm{cm}$ depth. Two treatments were used: irrigated and stressed, according to Souza et al. (2014). In the first treatment, water replacement was carried 
out every day until soil moisture was close to field capacity, of $-18 \mathrm{kPa}$ (Souza et al., 2013), whereas, in the second treatment, water stress was performed daily by applying at least $50 \%$ of the total water available, i.e., until the soil water tension reached at least $-138 \mathrm{kPa}$; this value was established according to the soil water retention curve. Stress was maintained for ten days. In order to achieve this, water stress was imposed at three critical stages of development: V5, VT, and R3. Cumulative stresses were also imposed by combining these growth stages: V5VT, V5R3, VTR3, and V5VTR3, resulting in two and three times the stress during the life cycle of corn. Therefore, eight treatments were applied: seven under stress and one irrigated.

For the evaluation of root morphology, two roots of each pot were collected from all treatments at the end of the R3 stage. After washing, the plants were separated into roots and shoots, at the root collar. To analyze the morphology of the root system, the WinRhizo Pro 2007a image analysis system (Regent Instruments Inc., Sainte-Foy, Quebec, Canada) was used, coupled to a professional scanner Epson Expression $10000 \mathrm{XL}$ (Epson America, Inc., Long Beach, CA, USA) equipped with an additional light unit (TPU). The images were obtained according to Souza et al. (2012). The evaluated traits were: root length $(\mathrm{cm})$, which was also analyzed by diameter classes ( 0 to $4.5 \mathrm{~mm}$ ) using the same software; root surface area $\left(\mathrm{cm}^{2}\right)$; and root volume $\left(\mathrm{cm}^{3}\right)$. Roots were then stored in paper bags and maintained in a forced air circulation oven, at $72^{\circ} \mathrm{C}$, until constant mass. Specific length $\left(\mathrm{cm} \mathrm{g}^{-1}\right)$ was also assessed. In the analysis of root morphology, the index of relative value of tolerance (RVT) was obtained to express the tolerance of each hybrid, representing the values of each trait under stress divided by the values under the irrigated treatment (Souza et al., 2013).

For the analysis of root anatomy, one root (with all parts) was collected from two plants per treatment per replicate. For each treatment under water deficit, roots from the corresponding treatment under irrigation (control) were also collected. The cross-sections were done according to Souza et al. (2009) and photographed in an optical light microscope, model Olympus BX60 (Olympus Corporation of the Americas, Center Valley, PA, USA), coupled to a digital camera. The following parameters were analyzed in the root: cortex thickness; proportion of aerenchyma in the cortex; width of the suberized cell layer, present in the hypodermis region (exodermis); endoderm thickness; diameter; number of cells of the metaxylem; and phloem thickness. The proportion of area occupied by the aerenchyma in the cortex was calculated by dividing the total area of the aerenchyma by the total area of the cortex. All these measurements were made by the UTHSCSA ImageTool analysis software (University of Texas, San Antonio, TX, USA), according to Souza et al. (2009).

The number of ears, ear length, and grain yield were determined at harvest. The experimental design was a randomized complete block in a factorial arrangement with eight treatments, two hybrids, and five replicates. For anatomical characteristics, only eight treatments were shown, since there was no statistical difference between the two hybrids. Means \pm standard-error were calculated for each parameter. For statistical analyses, the analysis of variance (Anova) was carried out and means were compared by the Scott-Knott test, at 5\% probability, using the Sisvar software, version 4.3 (Universidade Federal de Lavras, Lavras, MG, Brazil).

\section{Results and Discussion}

The highest means for root length, surface area, and volume were observed in the irrigated treatment, with no significant differences between hybrids (Table 1).

Comparing hybrids, total root length was greater when water stress was imposed at the V5, VT, and V5VT stages for BRS 1030, but at V5R3, VTR3, and V5VTR3 for DKB 390. No differences, however, were observed among hybrids under water stress at the R3 stage. Comparing treatments, DKB 390 showed the lowest values for root length when water stress was imposed at the vegetative and flowering stages, i.e., V5, VT, and V5VT, and the highest values at V5R3, VTR3, and V5VTR3. The BRS 1030 hybrid exceeded DKB 390 only when stress was imposed at V5 and VT; in the other treatments, the values for the sensitive hybrid were lower. Root surface area and length were similar for both hybrids. DKB 390 showed higher root surface area under cumulative stress and in the treatments that overcame R3; however, the opposite occurred in BRS 1030, which presented lower surface area at these stages.

Regarding root volume, higher means were obtained with stress imposition for DKB 390 at the V5R3, VTR3, and R3 stages, and for BRS 1030 at V5 and

Pesq. agropec. bras., Brasília, v.51, n.4, p.330-339, abr. 2016

DOI: $10.1590 / \mathrm{S} 0100-204 X 2016000400005$ 
VT (Table 1). The lowest and highest root volumes for the tolerant and susceptible hybrids, respectively, were observed at the V5, VT, and V5VT stages.

In most cases, DKB 390 showed the best morphological characteristics of roots under stress at the reproductive stages (R3) and in the cumulative treatments, whereas BRS 1030 presented better performance with stress imposition at the vegetative and flowering stages (V5, VT, and V5VT). Despite cumulative drought imposition in three periods (V5VTR3), DKB 390 presented greater root length and root surface area than BRS 1030; these parameters are important morphological markers of drought tolerance. In alignment with the present study, Ali et al. (2016) found that tolerant genotypes have greater root length in the flowering stage. Li et al. (2011), while evaluating corn under drought stress, observed that there was an increase in root length, volume, and superficial area. As water deficit increases, the upper soil layers are generally the first to dry. Therefore, when all the soil layers are moistened, the plants develop a predominantly superficial root system, and, when the water ends in the superficial layers of the soil, the loss of roots and proliferation of deeper roots occur (Li et al., 2011). The growth and deepening of the root system to maintain water absorption can be considered a way to protect against drought. In some crops, such as rice (Anantha et al., 2016), sorghum (Magalhães et al., 2016) and corn (Grieder et al., 2014), a more developed and deeper root system contributes substantially to improve performance under water stress. However, according to Imada et al. (2008), root surface area is more related to the absorption of nutrients.
The analysis of the distribution of root length per diameter classes showed a similar behavior to that of the morphological attributes already described. In all treatments in which drought imposition surpassed R3 (V5R3, VTR3, V5VTR3, and R3), a greater length of fine roots, that is, roots with a diameter smaller than $1 \mathrm{~mm}$, was observed for the tolerant hybrid DKB 390 (Figure 1); BRS 1030 presented better performance at V5, VT, and V5VT. This behavior was also detected when the irrigated treatment was analyzed through the stress index. Lavinsky et al. (2015) studied the DKB 390 hybrid under drought imposed only at the flowering stage and reported no changes in the length of fine roots. However, Hund et al. (2009) concluded that the tolerant genotype, CML44, presents greater length of fine roots at the V5 growth stage.

Specific root length was higher for DKB 390 in all treatments, except in V5VT, in which no differences were found, and in V5, in which BRS 1030 presented greater values (Table 1). For DKB 390, the highest value was observed at V5VTR3 and the lowest ones at V5, V5VT, V5R3, and in the irrigated treatment. For BRS 1030, the highest length was found when stress imposition occurred at the V5, VT, and R3 stages. Chimungu et al. (2014), while evaluating tolerant corn genotypes in a greenhouse, reported higher specific root length at early stages (seedlings).

The greater length of fine roots (root distribution by diameter classes) found for DKB 390 in various treatments represents greater chances of water absorption, since these roots are responsible for this function according to Eissenstat (1992). Thick roots are more related to the setting of the plant in the soil,

Table 1. Morphological characteristics of roots of two corn (Zea mays) hybrids contrasting for drought tolerance (DKB 390, tolerant; and BRS 1030, susceptible) at different stages of development ${ }^{(1)}$.

\begin{tabular}{|c|c|c|c|c|c|c|c|c|}
\hline \multirow[t]{2}{*}{ Treatment } & \multicolumn{2}{|c|}{ Root lenght $(\mathrm{cm})$} & \multicolumn{2}{|c|}{ Root surface area $\left(\mathrm{cm}^{2}\right)$} & \multicolumn{2}{|c|}{ Root volume $\left(\mathrm{cm}^{3}\right)$} & \multicolumn{2}{|c|}{ Specific root length $\left(\mathrm{cm} \mathrm{g}^{-1}\right)$} \\
\hline & DKB 390 & BRS 1030 & DKB 390 & BRS 1030 & DKB 390 & BRS 1030 & DKB 390 & BRS 1030 \\
\hline$\overline{\mathrm{V} 5}$ & $27,398 \pm 437 \mathrm{cB}$ & $48,132 \pm 329 \mathrm{bA}$ & $5,014 \pm 56 \mathrm{cB}$ & $7,798 \pm 70 \mathrm{bA}$ & $68 \pm 10 \mathrm{cB}$ & $105 \pm 10 \mathrm{bA}$ & $2,285 \pm 61 \mathrm{cB}$ & $2,865 \pm 29 \mathrm{aA}$ \\
\hline VT & $26,299 \pm 441 \mathrm{cB}$ & $44,817 \pm 111 \mathrm{bA}$ & $4,217 \pm 51 \mathrm{cB}$ & $7,769 \pm 72 \mathrm{bA}$ & $55 \pm 7 \mathrm{cB}$ & $113 \pm 23 \mathrm{bA}$ & $3,120 \pm 41 \mathrm{bA}$ & $2,511 \pm 43 \mathrm{aB}$ \\
\hline R3 & $37,831 \pm 337 \mathrm{bA}$ & $29,691 \pm 300 \mathrm{cA}$ & $5,941 \pm 12 \mathrm{cA}$ & $5,103 \pm 39 \mathrm{cA}$ & $89 \pm 11 \mathrm{bA}$ & $72 \pm 9 \mathrm{cB}$ & $3,239 \pm 16 \mathrm{bA}$ & $2,607 \pm 62 \mathrm{aB}$ \\
\hline V5VT & $19,960 \pm 549 \mathrm{cB}$ & $32,153 \pm 264 \mathrm{cA}$ & $4,217 \pm 65 \mathrm{cB}$ & $7,548 \pm 42 \mathrm{bA}$ & $70 \pm 11 \mathrm{cB}$ & $99 \pm 7 \mathrm{bA}$ & $2,107 \pm 77 \mathrm{cA}$ & $2,369 \pm 22 \mathrm{bA}$ \\
\hline V5R3 & $43,270 \pm 132 \mathrm{bA}$ & $29,200 \pm 259 \mathrm{cB}$ & $6,980 \pm 26 \mathrm{bA}$ & $5,888 \pm 13 \mathrm{cB}$ & $91 \pm 9 \mathrm{bA}$ & $65 \pm 12 \mathrm{cB}$ & $2,674 \pm 37 \mathrm{cA}$ & $2,029 \pm 25 \mathrm{bB}$ \\
\hline VTR3 & $48,925 \pm 221 \mathrm{bA}$ & $36,213 \pm 301 \mathrm{cB}$ & $7,464 \pm 39 \mathrm{bA}$ & $6,557 \pm 31 \mathrm{cB}$ & $94 \pm 10 \mathrm{bA}$ & $77 \pm 9 \mathrm{cB}$ & $3,307 \pm 20 \mathrm{bA}$ & $2,160 \pm 11 b B$ \\
\hline V5VTR3 & $53,522 \pm 100 \mathrm{bA}$ & $29,147 \pm 300 \mathrm{cB}$ & $7,704 \pm 18 \mathrm{bA}$ & $6,434 \pm 66 \mathrm{cB}$ & $94 \pm 10 \mathrm{bA}$ & $68 \pm 12 \mathrm{cA}$ & $4,492 \pm 55 \mathrm{aA}$ & $2,260 \pm 34 \mathrm{bB}$ \\
\hline Irrigated & $69,208 \pm 240 \mathrm{aA}$ & $64,515 \pm 412 \mathrm{aA}$ & $8,316 \pm 90 \mathrm{aA}$ & $8,291 \pm 98 \mathrm{aA}$ & $110 \pm 31 \mathrm{aA}$ & $145 \pm 40 \mathrm{aA}$ & $2,906 \pm 63 \mathrm{cA}$ & $2,349 \pm 40 \mathrm{bB}$ \\
\hline
\end{tabular}

${ }^{(1)}$ Means followed by the equal letters, lowercase in the columns and uppercase in the lines for hybrids, do not differ by the Scott-Knott test, at $5 \%$ probability. Each value indicates the mean of treatment \pm standard-error. 


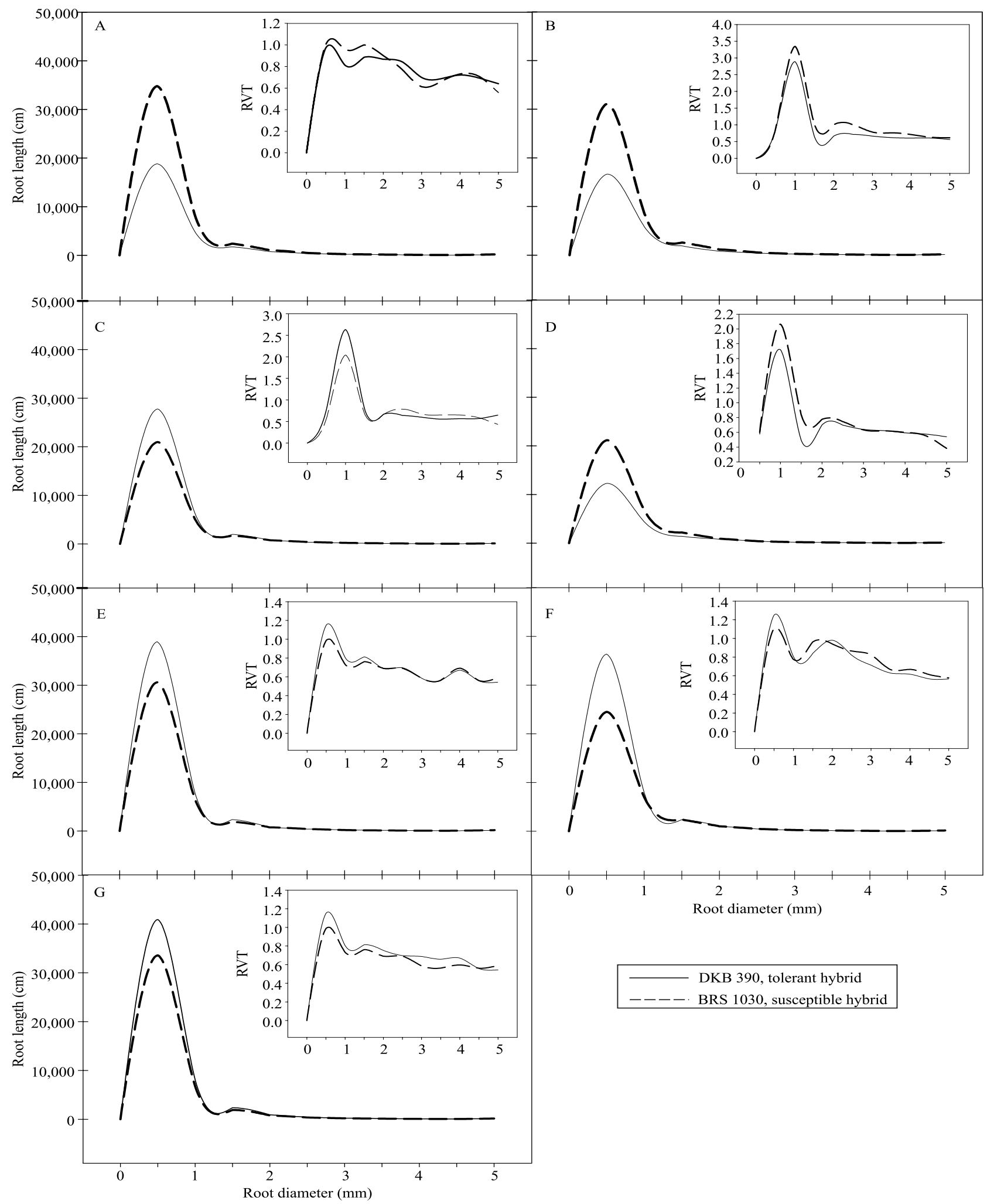

Figure 1. Root length distributed by diameter classes in two corn (Zea mays) hybrids contrasting for drought tolerance at different stages of development: A, V5; B, VT; C, R3; D, V5VT; E, V5R3; F, VTR3; and G, V5VTR3. DKB 390, tolerant hybrid, represented by a continuous line; and BRS 1030, susceptible hybrid, represented by a dashed line. RVT, index of relative value of tolerance. 
whereas the production of fine roots with a larger surface area per mass unit is a mechanism used to enhance the uptake of water and nutrients in dry conditions. Consequently, there is an increase in the specific length and surface area of the root system that may lead to a greater tolerance to drought. Theoretically, a higher specific root length results in higher exploration and absorption of water and nutrients from the soil per carbon unit invested. Therefore, in an unfavorable environment, with water deficit, for example, root growth is very important in order to allow a greater exploration of the soil in search of water, without excessive energy consumption (Ryser, 2006).

Regarding root anatomy, no differences were observed for cortex thickness among treatments for
DKB 390 and BRS 1030 (Figure 2 A). Water stress increased the proportion of aerenchyma in the cortex of the two studied hybrids (Figure $2 \mathrm{~B}$ and Figure 3). For DKB 390, the proportion of aerenchyma in the cortex was higher at V5VTR3 and R3, followed by the other two treatments with water stress imposition at the reproductive stages, i.e., V5R3 and VTR3 (Figure 3). In the treatments with stress, BRS 1030 also presented high proportions of aerenchyma - the highest were found at VT, R3, VTR3, and V5VTR3 (Figure 3). It should be pointed out that treatments with irrigation resulted in the lowest proportions of aerenchyma for both DKB 390 and BRS 1030. Exoderm thickness did not change with the imposition of stress in any of the hybrids (Figure $2 \mathrm{C}$ ); however, differences

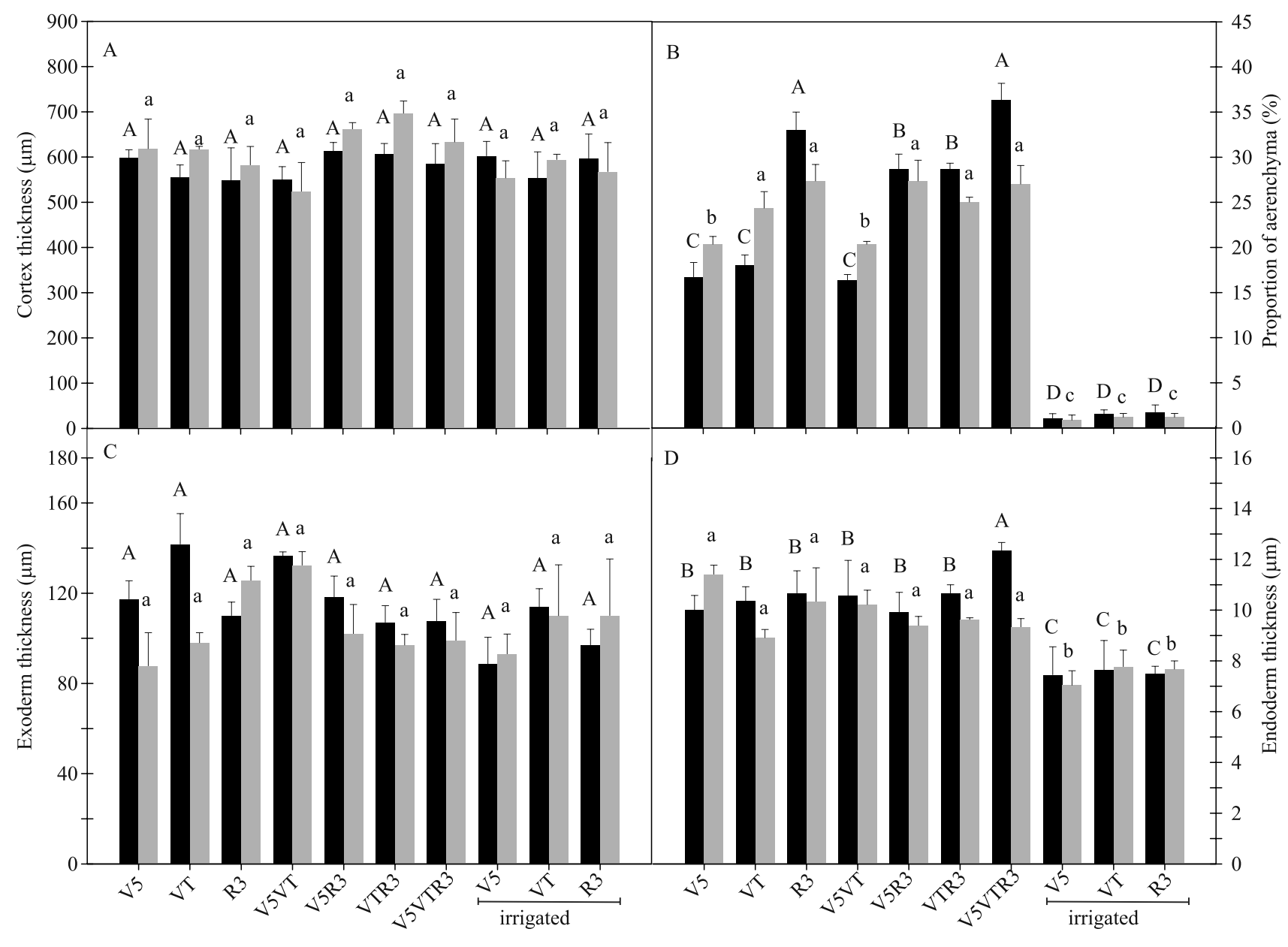

Growth stages

$\square$ DKB $390 \quad \square$ BRS 1030

Growth stages

Figure 2. Anatomical characteristics of root cortex in two corn (Zea mays) hybrids contrasting for drought tolerance at different stages of development: V5, VT, R3, V5VT, V5R3, VTR3, and V5VTR3. DKB 390, tolerant; and BRS 1030, susceptible. Each bar indicates the mean of treatment \pm standard error. Means followed by equal letters, uppercase for DKB 390 and lowercase for BRS 1030, do not differ by the Scott-Knott test, at 5\% probability. 
were observed for the innermost apoplastic barrier (endoderm) (Figure 2 D). For DKB 390, endoderm thickness was significantly higher at V5VTR3, followed by all other treatments with drought imposition, whereas, for BRS 1030, differences were found between stressed and irrigated treatments, being lower in the irrigated ones.

These results are important, since endoderm and exoderm are layers of cells in the roots that act as important barriers; a greater thickness after stressed treatments may indicate that the water cannot pass from the xylem vessels to the soil, which would avoid dehydration (Souza et al., 2013).

Even though no differences were found in the present study, the cortical region of corn roots has been the focus of breeding programs for tolerance to water deficit. Chimungu et al. (2014) and Jaramillo et al. (2013) reported that larger cells of the root cortical parenchyma reduce cellular respiration in this region, contributing to the deepening of the root system due to a lower metabolic cost, and that corn plants with lower cortex have higher drought tolerance, due to the smaller number of cell rows. Aerenchyma in corn roots may have the function of supporting a greater soil and water acquisition, since these structures decrease the metabolic cost of growing roots because of the reduced presence of cells in respiration (Zhu et al., 2010; Souza et al., 2013). Therefore, the greater root system observed in the tolerant hybrid may be attributed to a higher proportion of aerenchyma in the cortex.

In DKB 390, the diameter of metaxylem cells was lower under stress but there were no differences within each treatment group (Figure $4 \mathrm{~A}$ ). Conversely, no difference between treatments was observed for BRS 1030, except at V5VT. The number of metaxylem vessels and phloem thickness were similar in all treatments and for both hybrids (Figure $4 \mathrm{~B}$ and C). In addition, the presence of xylem vessels with smaller diameter in the roots of the DKB 390 hybrid, under drought stressed treatments, can support the retention of water in plants. Although no differences were found in the present work, the increase in the number of metaxylem vessels can also promote water conservation. Souza et al. (2013) and Li et al. (2009) reported a greater amount of metaxylems for drought tolerant corn genotypes. These characteristics
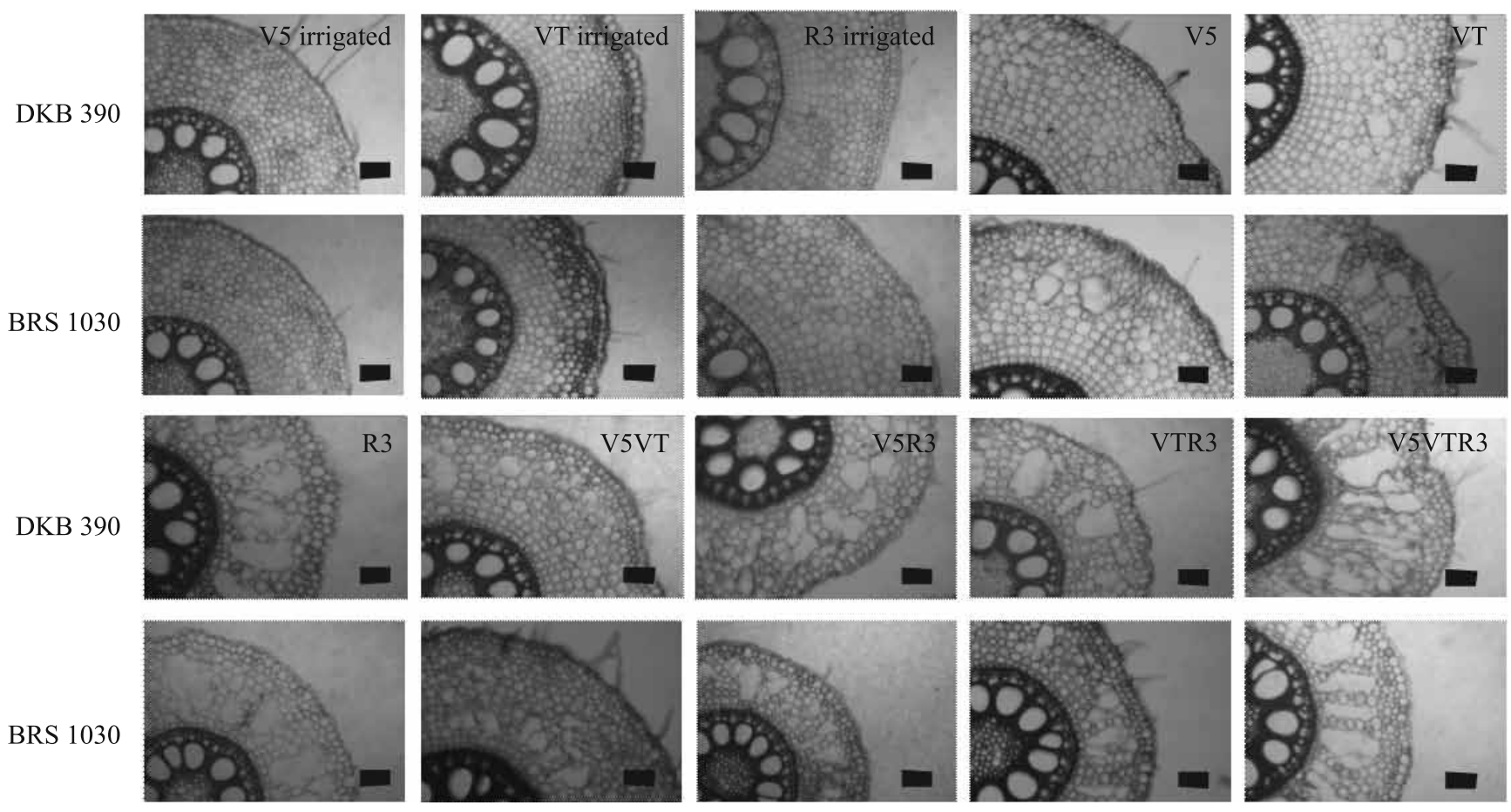

Figure 3. Photomicrographs of cross-sections of roots of two corn (Zea mays) hybrids contrasting for drought tolerance at different stages of development: V5, VT, R3, V5VT, V5R3, VTR3, and V5VTR3. DKB 390, tolerant; and BRS 1030, susceptible. a, aerenchyma. Bars correspond to $100 \mu \mathrm{m}$. 

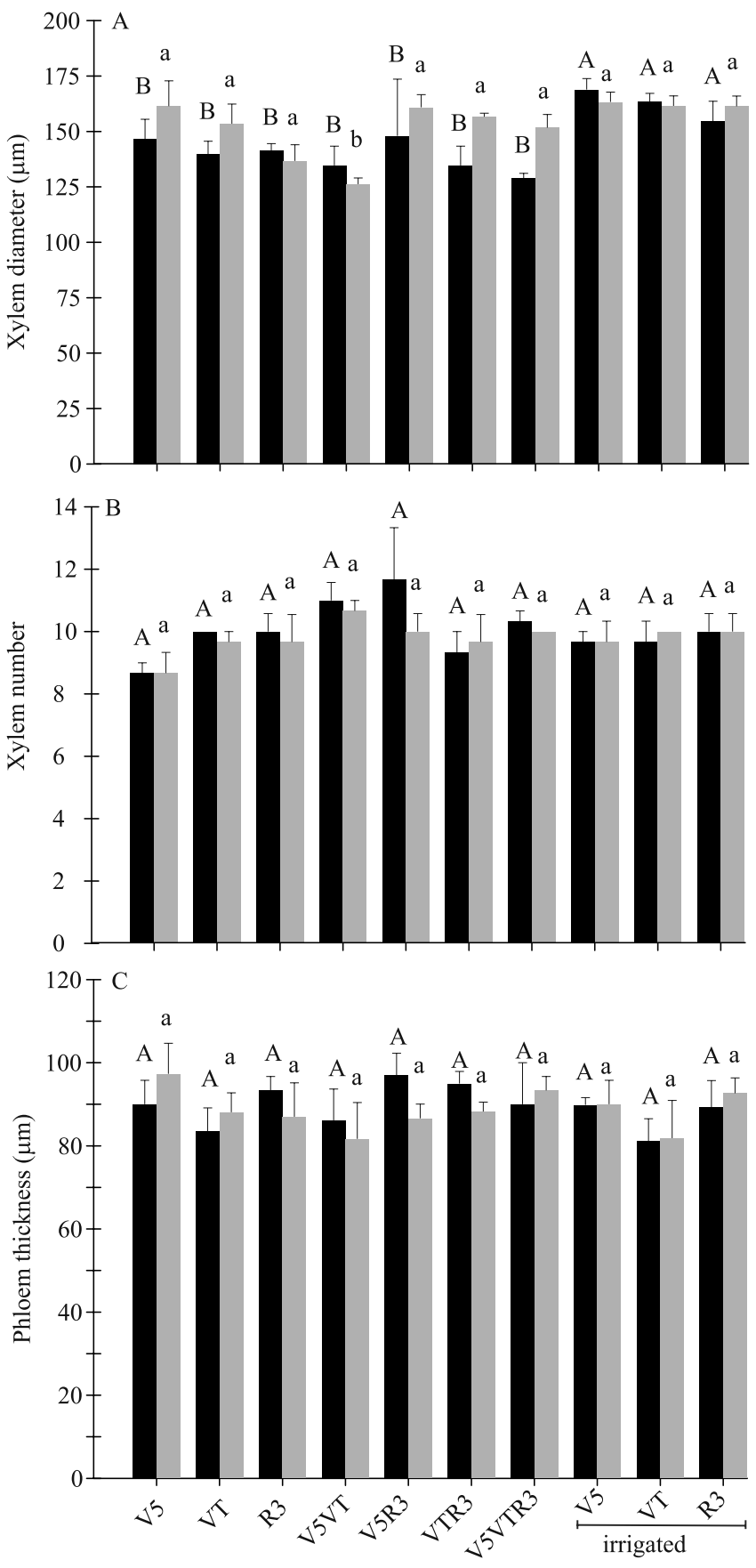

Growth stages

$\square$ DKB $390 \quad \square$ BRS 1030

Figure 4. Anatomical characteristics of root vessels in two corn (Zea mays) hybrids contrasting for drought tolerance at different stages of development: V5, VT, R3, V5VT, V5R3, VTR3, and V5VTR3. DKB 390, tolerant; and BRS 1030, susceptible. Each bar indicates the mean of treatment \pm standard-error. Means followed by equal letters, uppercase for DKB 390 and lowercase for BRS 1030, do not differ by the Scott-Knott test, at $5 \%$ probability. may indicate a higher hydraulic conductivity, which increases the water transport capacity. This can be explained by the more apparent effect of drought in the xylem vessels of corn, i.e., by the reduction of hydraulic conductance, which occurs either because of the lack of available water or because of the low activity/expression of aquaporin (proteins responsible for the transport of water into the roots). Without water in the xylem (tracheid and vessel elements), air bubbles can be formed (embolism) or flow can be interrupted (cavitation) due to stretching (breaking) of the water column (Li et al., 2009). A study showed that thicker phloem in corn under stress may favor the influx of photoassimilates coming from the shoots (Souza et al., 2009).

Regarding yield components, no significant differences were detected for ear length and diameter between hybrids, except for ear diameter at V5VT (Table 2). Comparing hybrids, grain yield was higher for DKB 390 at V5R3, VTR3, and V5VTR3 (Table 2), but, for BRS 1030, only at the VT stage. Comparing DKB 390 under drought stress, the highest grain yield was observed in the irrigated treatment, followed by V5R3, VTR3, and V5VTR3; lower yields were found in all the other treatments. For the BRS 1030 hybrid, the highest grain yield was also obtained in the irrigated treatment, but, among the stressed treatments, V5 surpassed the others. Ge et al. (2012) also found that water stress is highly dependent on stages of development and on drought intensity and duration; these authors observed differences in plant morphophysiology and yield. In the present study, the sensitive hybrid, BRS 1030, presented higher means for the evaluated parameters, mainly at the V5 and VT stages, but without resulting in higher grain yield. The DKB 390 hybrid presented: a higher grain yield, confirming its drought tolerance; a larger root system, including total root length, fine root length, root surface area, and specific root length; and anatomical changes in the aerenchyma, especially under cumulative stresses, which can be explained by drought memory. Recently, some studies involving drought, cold, and heat stresses, as well as nutrient deficiency, have indicated that plants may have an ecological stress memory (Walter et al., 2013). The more stress the plant cumulatively experiences, the greater will be the adaptations to survive the next phase of stress. This acclimatization after the first stress may involve mechanisms such 
Table 2. Yield traits of two corn (Zea mays) hybrids contrasting for drought tolerance (DKB 390, tolerant; and BRS 1030, susceptible) at different stages of development ${ }^{(1)}$.

\begin{tabular}{|c|c|c|c|c|c|c|}
\hline \multirow[t]{2}{*}{ Treatment } & \multicolumn{2}{|c|}{ Ear length $(\mathrm{cm})$} & \multicolumn{2}{|c|}{ Ear diameter $(\mathrm{mm})$} & \multicolumn{2}{|c|}{ Grain yield (g per plant) } \\
\hline & DKB 390 & BRS 1030 & DKB 390 & BRS 1030 & DKB 390 & BRS 1030 \\
\hline$\overline{\mathrm{V} 5}$ & $9.6 \pm 0.7 \mathrm{aA}$ & $9.9 \pm 1.7 \mathrm{aA}$ & $40 \pm 1.0 \mathrm{aA}$ & $37 \pm 6.0 \mathrm{aA}$ & $80 \pm 4 \mathrm{cA}$ & $99 \pm 6 \mathrm{bA}$ \\
\hline VT & $7.6 \pm 0.6 \mathrm{aA}$ & $10.8 \pm 2.0 \mathrm{aA}$ & $30 \pm 7.5 \mathrm{aA}$ & $33 \pm 5.6 \mathrm{aA}$ & $53 \pm 5 \mathrm{cB}$ & $79 \pm 5 \mathrm{cA}$ \\
\hline R3 & $9.9 \pm 0.7 \mathrm{aA}$ & $8.5 \pm 0.7 \mathrm{aA}$ & $46 \pm 1.2 \mathrm{aA}$ & $38 \pm 2.0 \mathrm{aA}$ & $79 \pm 2 \mathrm{cA}$ & $74 \pm 1 \mathrm{cA}$ \\
\hline V5VT & $10.0 \pm 0.8 \mathrm{aA}$ & $10.6 \pm 1.0 \mathrm{aA}$ & $46 \pm 1.6 \mathrm{aA}$ & $30 \pm 5.0 \mathrm{aB}$ & $65 \pm 2 \mathrm{cA}$ & $52 \pm 7 \mathrm{cA}$ \\
\hline V5R3 & $12.8 \pm 0.8 \mathrm{aA}$ & $9.0 \pm 1.2 \mathrm{aA}$ & $46 \pm 1.0 \mathrm{aA}$ & $36 \pm 1.5 \mathrm{aA}$ & $114 \pm 6 \mathrm{bA}$ & $66 \pm 3 \mathrm{cB}$ \\
\hline VTR3 & $10.0 \pm 0.7 \mathrm{aA}$ & $9.0 \pm 0.7 \mathrm{aA}$ & $42 \pm 2.2 \mathrm{aA}$ & $33 \pm 1.7 \mathrm{aA}$ & $113 \pm 9 \mathrm{bA}$ & $62 \pm 6 \mathrm{cB}$ \\
\hline V5VTR3 & $10.1 \pm 1.7 \mathrm{aA}$ & $9.3 \pm 0.5 \mathrm{aA}$ & $37 \pm 3.0 \mathrm{aA}$ & $35 \pm 1.7 \mathrm{aA}$ & $111 \pm 9 \mathrm{bA}$ & $68 \pm 2 \mathrm{cB}$ \\
\hline Irrigated & $13.7 \pm 0.2 \mathrm{aA}$ & $12.9 \pm 0.5 \mathrm{aA}$ & $50 \pm 1.0 \mathrm{aA}$ & $45 \pm 1.2 \mathrm{aA}$ & $147 \pm 4 \mathrm{aA}$ & $149 \pm 2 \mathrm{aA}$ \\
\hline
\end{tabular}

${ }^{(1)}$ Means followed by equal letters, lowercase in the columns for treatments and uppercase in the lines for hybrids, do not differ by the Scott-Knott test, at $5 \%$ probability. Each value indicates the mean of treatment \pm standard error.

as: accumulation of osmoprotectants and soluble sugars; changes in mediators of ABA-triggered gene expression; increase in the sequestration mechanisms of reactive oxygen species; and morphological changes, including increased root system, among others (Walter et al., 2013).

Physiological studies with Arrhenatherum elatius grass showed that the plants acclimated after a first drought stress became more tolerant to a second cumulative stress (Walter et al., 2011). Taking into account the photoprotective mechanisms that led to increased biomass in the plants subjected to cumulative stress, when compared to those that were not, these authors concluded that there is drought memory.

\section{Conclusions}

1. The greater tolerance of the DKB 390 corn (Zea mays) hybrid to water deficit is linked with the memory of pre-exposure to water stress at different development stages.

2. Tolerant corn genotypes present a greater root system, mainly of fine roots, and greater proportions of aerenchyma.

\section{Acknowledgments}

To Coordenação de Aperfeiçoamento de Pessoal de Nível Superior (Capes), for the scholarship; and to Fundação de Amparo à Pesquisa do Estado de Minas Gerais (Fapemig, Process No. APQ-01433-10), for financial support.

\section{References}

ALI, M.L; LUETCHENS, J.; SINGH, A.; SHAVER, T.M.; KRUGER, G.R.; LORENZ, A.J. Greenhouse screening of maize genotypes for deep root mass and related root traits and their association with grain yield under water-deficit conditions in the field. Euphytica, v.207, p.79-94, 2016. DOI: 10.1007/s10681-0151533-x.

ANANTHA, M.S.; PATEL, D.; QUINTANA, M.; SWAIN, P.; DWIVEDI, J.L.; TORRES, R.O.; VERULKAR, S.B.; VARIAR, M.; MANDAL, N.P.; KUMAR, A.; HENRY, A. Trait combinations that improve rice yield under drought: Sahbhagi Dhan and new drought-tolerant varieties in South Asia. Crop Science, v.56, p.408-442, 2016. DOI: 10.2135/cropsci2015.06.0344.

ARAUS, J.L.; SERRET, M.D.; EDMEADES, G.O. Phenotyping maize for adaptation to drought. Frontiers in Physiology, v.3, p.305, 2012. DOI: 10.3389/fphys.2012.00305.

BURTON, A.L.; JOHNSON, J.; FOERSTER, J.; HANLON, M.T.; KAEPPLER, S.M.; LYNCH, J.P.; BROWN, K.M. QTL mapping and phenotypic variation of root anatomical traits in maize (Zea mays L.). Theoretical and Applied Genetics, v.128, p.93-106, 2015. DOI: $10.1007 / \mathrm{s} 00122-014-2414-8$.

CHIMUNGU, J.G.; BROWN, K.M.; LYNCH, J.P. Reduced root cortical cell file number improves drought tolerance in maize. Plant Physiology, v.166, p.1943-1955, 2014. DOI: 10.1104/ pp.114.249037.

EISSENSTAT, D.M. Costs and benefits of constructing roots of small diameter. Journal of Plant Nutrition, v.15, p.763-782, 1992. DOI: $10.1080 / 01904169209364361$.

GE, T.; SUI, F.; BAI, L.; TONG, C.; SUN, N. Effects of water stress on growth, biomass partitioning, and water-use efficiency in summer maize (Zea mays L.) throughout the growth cycle. Acta Physiologiae Plantarum, v.34, p.1043-1053, 2012. DOI: 10.1007/ s11738-011-0901-y.

GONG, F.; WU, X,; ZHANG, H.; CHEN, Y.; WANG, W. Making better maize plants for sustainable grain production in a changing 
climate. Frontiers in Plant Science, v.6, p.1-6, 2015. DOI: 10.3389/fpls.2015.00835.

GRIEDER, C.; TRACHSEL, S.; HUND, A. Early vertical distribution of roots and its association with drought tolerance in tropical maize. Plant and Soil, v.377, p.295-308, 2014. DOI: 10.1007/s11104-013-1997-1.

HUND, A.; RUTA, N.; LIEDGENS, M. Rooting depth and water use efficiency of tropical maize inbred lines, differing in drought tolerance. Plant and Soil, v.318, p.311-325, 2009. DOI: 10.1007/ s11104-008-9843-6.

IMADA, S.; YAMANAKA, N.; TAMAI, S. Water table depth effects Populus alba fine root growth and whole plant biomass. Functional Ecology, v.22, p.1018-1026, 2008. DOI: 10.1111/j.1365-2435.2008.01454.x.

JARAMILLO, R.E.; NORD, E.A.; CHIMUNGU, J.G.; BROWN, K.M.; LYNCH, J.P. Root cortical burden influences drought tolerance in maize. Annals of Botany, v.112, p.429-437, 2013. DOI: $10.1093 / \mathrm{aob} / \mathrm{mct} 069$.

KHODARAHMPOUR, Z.; HAMIDI, J. Evaluation of drought tolerance in different growth stages of maize (Zea mays L.) inbred lines using tolerance indices. African Journal of Biotechnology, v.10, p.13482-13490, 2011. DOI: 10.5897/ajb11.2193.

KUMAR, B.; ABDEL-GHANI, A.H.; REYES-MATAMOROS, J.; HOCHHOLDINGER, F.; LÜBBERSTEDT, T. Genotypic variation for root architecture traits in seedlings of maize (Zea mays L.) inbred lines. Plant Breeding, v.131, p.465-478, 2012. DOI: 10.1111/j.1439-0523.2012.01980.x.

LAVINSKY, A.O.; MAGALHÃES, P.C.; ÁVILA, R.G.; DINIZ, M.M.; SOUZA, T.C. de. Partitioning between primary and secondary metabolism of carbon allocated to roots in four maize genotypes under water deficit and its effects on productivity. The Crop Journal, v.3, p.379-386, 2015. DOI: 10.1016/j. cj.2015.04.008.

LI, C.; SUN, J.; LI, F.; ZHOU, X.; LI, Z.; QIANG, X.; GUO, D. Response of root morphology and distribution in maize to alternate furrow irrigation. Agricultural Water Management, v.98, p.17891798, 2011. DOI: 10.1016/j.agwat.2011.07.005.

LI, Y.; SPERRY, J.S.; SHAO, M. Hydraulic conductance and vulnerability to cavitation in corn (Zea mays L.) hybrids of differing drought resistance. Environment and Experimental Botany, v.66, p.341-346, 2009. DOI: 10.1016/j.envexpbot.2009.02.001.

MAGALHÃES, P.C.; DURÃES, F.O.M. Fisiologia da produção. In: CRUZ, J.C.; KARAM, D.; MONTEIRO, M.A.R.; MAGALHÃES, P.C. (Ed.). A cultura do milho. Sete Lagoas: Embrapa Milho e Sorgo, 2008. p.63-87.

MAGALHÃES, P.C.; SOUZA, T.C. de; LAVINSKY, A.O.; ALBUQUERQUE, P.E.P. de; OLIVEIRA, L.L. de; CASTRO, E.M. de. Phenotypic plasticity of root system and shoots of Sorghum bicolor under different soil water levels during pre-flowering stage. Australian Journal of Crop Science, v.10, p.81-87, 2016.

RYSER, P. The mysterious root length. Plant and Soil, v.286, p.16, 2006. DOI: 10.1007/s11104-006-9096-1.

SOUZA, T.C. de; CASTRO, E.M. de; MAGALHÃES, P.C.; ALVES, E.T.; PEREIRA, F. J. Early characterization of maize plants in selection cycles under soil flooding. Plant Breeding, v.131, p.493-501, 2012. DOI: 10.1111/j.14390523.2012.01973.x.

SOUZA, T.C. de; CASTRO, E.M. de; MAGALHÃES, P.C.; LINO, L. de O.; ALVES, E.T.; ALBUQUERQUE, P.E.P. de. Morphophysiology, morphoanatomy, and grain yield under field conditions for two maize hybrids with contrasting response to drought stress. Acta Physiologiae Plantarum, v.35, p.3201-3211, 2013. DOI: $10.1007 / \mathrm{s} 11738-013-1355-1$.

SOUZA, T.C. de; CASTRO, E.M. de; PEREIRA, F.J. ; PARENTONI, S.N. ; MAGALHÃES, P.C. Morpho-anatomical characterization of root in recurrent selection cycles for flood tolerance of maize (Zea mays L.). Plant, Soil and Environment, v.55, p.504-510, 2009.

SOUZA, T.C. de; MAGALHÃES, P.C.; CASTRO, E.M. de; CARNEIRO, N.P.; PADILHA, F.A.; GOMES JÚNIOR, C.C. ABA application to maize hybrids contrasting for drought tolerance: changes in water parameters and in antioxidant enzyme activity. Plant Growth Regulation, v.73, p.205-217, 2014. DOI: 10.1007/ s10725-013-9881-9.

WALTER, J.; JENTSCH, A.; BEIERKUHNLEIN, C.; KREYLING, J. Ecological stress memory and cross stress tolerance in plants in the face of climate extremes. Environmental and Experimental Botany, v.94, p.3-8, 2013. DOI: 10.1016/j. envexpbot.2012.02.009.

WALTER, J.; NAGY, L.; HEIN, R.; RASCHER, U.; BEIERKUHNLEIN, C.; WILLNER, E.; JENTSCH, A. Do plants remember drought? Hints towards a drought-memory in grasses. Environmental and Experimental Botany, v.71, p.34-40, 2011. DOI: 10.1016/j.envexpbot.2010.10.020.

YAN, W.; ZHONG, Y.; SHANGGUAN, Z. Evaluation of physiological traits of summer maize under drought stress. Acta Agriculturae Scandinavica, Section B - Soil and Plant Science, v.66, p.133-140, 2016.

ZHAN, A.; SCHNEIDER, H.; LYNCH, P.J. Reduced lateral root branching density improves drought tolerance in maize. Plant Physiology, v.168, p.1603-1615, 2015. DOI: 10.1104/pp.15.00187.

ZHU, J.; BROWN, K.M.; LYNCH, J.P. Root cortical aerenchyma improves the drought tolerance of maize (Zea mays L.). Plant, Cell and Environment, v.33, p.740-749, 2010.

Received on April 17, 2015 and accepted on March 11, 2016 